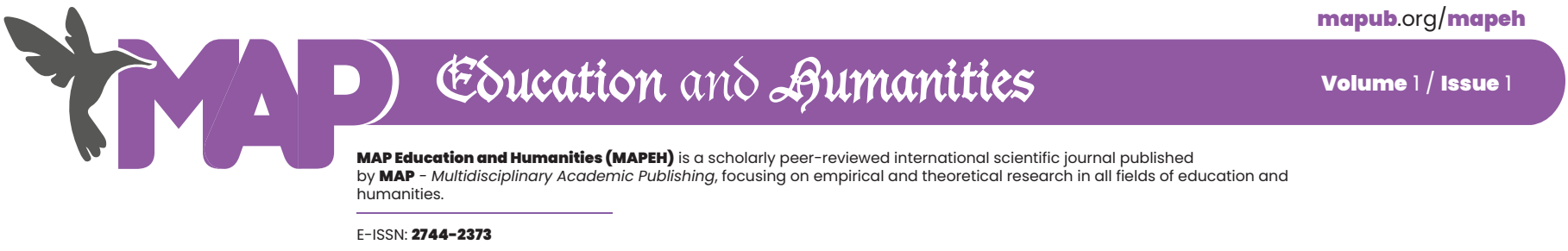

ORIGINAL RESEARCH PAPER

\title{
THE INFLUENCE OF ONLINE GAMES ON LEARNING ENGLISH VOCABULARY IN HIGH SCHOOLS IN BOSNIA AND HERZEGOVINA
}

\author{
Adela Mašić ', Aida Tarabar ${ }^{2}$ \\ The Fourth Gymnasium Ilidža, Sarajevo, Bosnia and Herzegovina \\ ${ }^{2}$ University of Zenica, Zenica, Bosnia and Herzegovina \\ Correspondence concerning this article should be addressed to Adela Mašić, The Fourth \\ Gymnasium Ilidža, Sarajevo, Bosnia and Herzegovina. E-mail: adela_masic@hotmail.com and \\ Aida Tarabar, University of Zenica, Zenica, Bosnia and Herzegovina. \\ E-mail: aidatarabar@gmail.com
}

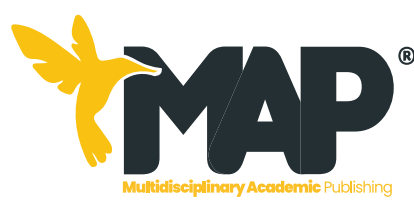

MAP EDUCATION AND HUMANITIES

Volume 1 / Issue 1

ISSN: 2744-2373/ @ 2021 The Authors. Published by MAP - Multidisciplinary Academic Publishing

Article Submitted: 20 May 202 Article Accepted: 30 June 202 Article Published: 20 August 202

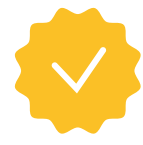

Publisher's Note: MAP stays neutral wit regard to jurisdictional claims in published

\section{ABSTRACT}

In the last couple of years, there has been an obvious increase in the number of school children proficient in English. One of the main reasons is the influence of the media, as well as students' great exposure to video games. The aim of this study was to investigate the connection between video-game playing and English language proficiency based on age, gender and latest grade in English language. A questionnaire was completed by 71 middle and high school students answering a range of questions on the quantity and quality of the video game they play. The results showed that video games have a great impact on language learning, as well as that vocabulary and communication are areas of most benefit. Therefore, as a form of highly desirable entertainment, video games provide a positive and motivating atmosphere which is perfect for adopting a foreign language and may have positive impacts on obtaining and improving vocabulary.

Keywords: online games, language learning, English vocabulary, communication, proficiency 


\section{Eoveation and \&umanities \\ by MAP - Multidisciplinary Academic Publishing}

THE INFLUENCE OF ONLINE GAMES ON LEARNING ENGLISH VOCABULARY IN HIGH SCHOOLS IN BOSNIA AND HERZEGOVINA

Adela Mašić and Aida Tarabar

\section{Introduction}

Ever since English language became a lingua franca, people from all over the world started learning it. It has become the main part in the lives of many people, especially with the rise of the United States after the World War 2, the influence of English language is felt everywhere. Due to the development of modern information technology, as well as the development of globalization, the Internet revolutionized the way humans communicate and learn a language. Computers are used in almost every field of life, and the internet has become very important information source. Whilst adults are not that willing to use computers in such an extent, at home or at work; using computers and the internet has become natural for children.

Since the vocabulary is basis of any language, many studies have paid a special attention to that field, and various methods and strategies have been examined to find some appropriate ways to facilitate its acquisition. Due to the fact that the Internet has become an essential part of everyday life, it was taken in consideration as an important tool for obtaining and improving vocabulary. Although there are many advantages in using the Internet for vocabulary learning purposes, one of the most important is: intrinsic motivation for students due to the fact that it is a useful tool to communicate with people all over the world. Hence, vocabulary acquisition best occurs in a relaxed, motivating, and enjoyable environment. Therefore, games may be an important factor in creating such an environment.

The area of the internet that became very important for non-native English speakers was the development of video games. Lately, more and more people, especially children, started playing various video games. At the beginning, video games were not that useful in the process of acquiring new vocabulary, due to the fact that the first video games mostly consisted of a bunch of shapes created only for moving towards other objects, without any depth to the play besides being just a reflexive test. Most of them did not have any narrative context, and the graphic was really poor. Over the time, games became more and more complex regarding the game play and the story, thus becoming a great source for both passive and active language learning. With the development of the technology, video games have become more and more advanced, and are to be compared with the characters form the cartoons or movies, thus engaging the story, and becoming cultural icons. What is also relevant is that there are two very important advantages of these mediums: communication and interaction; both very important in increasing proficiency of the players. Each game has a platform for communication and discussion in order to find out how to pass the level, or complete some tasks, especially with the development of massively multiplayer online game (MMOG or MMO), which is a type of an online game with large number of players, typically from hundreds to thousands, and the language in use is English. These games enable players to $\mathrm{co}^{-}$ operate and compete with each other on the large scale, and most of the time players have to interact meaningfully with the people all over the world. Due to the different video game genres, the vocabulary used in games varies. Taking in consideration these advantages, video gaming has become a great tool in learning English vocabulary. Therefore, it seems appropriate to analyze the influence online games have in the process.

The aim of this study is to explore the influence of online games on learning English vocabulary in high schools in Bosnia and Herzegovina. First, relevant research was reviewed. Second, a questionnaire was given to middle and high school students attending The Fourth Gymnasium Ilidža about the influence of online games on their English language proficiency. Third, the results of the survey were analyzed. Finally, the question if online games contribute to learning English vocabulary was examined.

\section{Literature review}

Due to the increase in number of middle and high school students who play the online games, and in relation to the fact that students are coming to school more proficient in English language, there are a few studies that were conducted to analyze the influence of these games on the language learning processes. According to some, these games can have some negative effects such as excessive playing or gaming addiction (Petry and O'Brien, 2013), on the other hand, they also provide players with some benefits such as feelings of achievement and sense of community (Sublette and Mullan, 2012). What is more important for both, English teachers and learners is that these games provide great possibilities for education as well (González-González and Blanco-Izquierdo, 2012).

One of the most important factors in learning a language is motivation, and according to 


\section{Eoveation and \&umanities \\ by MAP - Multidisciplinary Academic Publishing}

THE INFLUENCE OF ONLINE GAMES ON LEARNING ENGLISH VOCABULARY IN HIGH SCHOOLS IN BOSNIA AND HERZEGOVINA

Adela Mašić and Aida Tarabar

some studies gamers/learners are more relaxed and motivated to interact, and they perform much better in terms of language skills (Rankin et al., 2006; Suh et al., 2010; Kim et al., 2013). According to Warschauer and Healey (1998, as cited in Sørensen $\&$ Meyer, 2007), games have often been utilized to increase motivation and authentic communicative practices, since they have been seen as an enjoyable factor in language learning. It is said that games create a fun environment, related with leisure activities, and most interactive games provide communicative activities while being played. In this case, the game players will be using language both to learn and be able to participate in games better (Sørensen \& Meyer, 2007). In order to play better they engage in authentic communication through listening, speaking, reading and writing in the target language -English, with other players (Rama et al., 2012).

What is important to state is that there are two different types of MMORPGs, commercial and educational type which can be used to facilitate FL/ L2 learning. The later, also called serious games, "include an identifiable teaching presence specifically for improving some aspect of language proficiency" (Hubbard \& Bradin Siskin., 2004, p.457). Serious, or educational games' main objectives are learning and behavior change (Connolly et al., 2012) and can provide some in-game rewards if tasks are accomplished (Nagle et al., 2014), leading then to a greater motivation.

Interesting study Reinders and Wattana (2011) discuss was done by Chen and Johnson (2004, as cited in Rudis \& Poštić, 2018). What they actually did was to use a commercial game NeverwinterNights (developed by Bioware in 2002) and added a language learning aspect to the game. According to Rudis and Poštić (2018) even non educational online game can be beneficial to learners if modified, the more experience the player has with the game, the better chance to acquire the skills needed for the language learning. Most of the video games provide a lot of vocabulary items, granting the player to use it in order to communicate with other players.

In the study done by Yip and Kwan (2006) titled "Online vocabulary games as a tool for teaching and learning English vocabulary", was stated that learners who play online vocabulary games tend to learn more appropriately and could retain the new words for a longer period in comparison to those who are not provided with the games. As long as games are fun, confidence boosting, motivating and relaxing the learners' interest will increase.

Besides motivation, one very important factor in learning a language is the willingness to communicate. One way to achieve that is through playing video games, MMORPGs, specifically. Since those games provide low-anxiety environment and have a multiplayer component, they are easy and natural way to produce language. The article "Video Games as Opportunity for Informal English Language Learning: Theoretical Considerations", R.G. da Silva, describes two particular skills that video games help improve: receptive skills (reading and listening) and expressive skills (writing and speaking) (da Silva, 2014). It is done by giving players particular vocabulary they then use within the proper context. Since most of the MMORPGs are played among non-native English players and native-speakers, it leads directly to better form of language acquisition (Rankin et al., 2006).

One more study was done by Theodorsen (2015), where he introduces the concept of TaskBased Language Teaching method, and proposes the notion of "task" being an activity or goal carried out using language, and thus helping to understand in what way video games have a great potential being language learning tools, because players are active in the world which provides linguistic input using visuals, stimuli and context. In addition to this, an article entitled "Playing video games: A waste of time .... Or not?" by Olli Uuskoskis (2011), researches two teenagers playing Final Fantasy $X$, as playing they repeat the dialogues spoken by the characters in the game. Being able to mimic the speech produced by the characters, the players are able to transfer the same words in their own vocabulary and outside the gaming situation (Uuskoski, 2011).

To conclude, in theory the influence of online games on language acquisition so far points to the fact that online video games can be used in teaching a language. Most studies agree that online video games provide extra stimuli e.g. visual cues, voice acting, narratives, context, discourse which, when paired with some linguistic resources, may enhance the learning process. Many researchers see the potential of video games to be "edutainment" (a combination of education and entertainment) (Rudis \& Poštić, 2018). On the other hand, some studies suggest that there are some drawbacks as well especially with older games, since they do not include language, or language barely relevant while playing. 


\section{Eucation and doumanities \\ by MAP - Multidisciplinary Academic Publishing}

THE INFLUENCE OF ONLINE GAMES ON LEARNING ENGLISH VOCABULARY IN HIGH SCHOOLS IN BOSNIA AND HERZEGOVINA

Adela Mašić and Aida Tarabar

The current study was guided by the following research question:

RQI: Do online games have any influence on learning English vocabulary for middle and high school students in Bosnia and Herzegovina?

\section{Methodology}

\section{Participants}

The research sample consists of 71 middle and high school students in Sarajevo, Bosnia and Herzegovina, whose native language is Bosnian. They learnt English language as a foreign language attending The Fourth Gymnasium Ilidža in the academic year 2019-2020, ranging from 15-19 years old, from the $1^{\text {st }}$ to the $4^{\text {th }}$ grade, and level of language from pre-intermediate to upper-intermediate.

\section{Instrument and procedure}

In order to collect data for the research paper an online questionnaire, Google form, created by the researcher was used. The main purpose of the questionnaire was to gather as much information as possible on the topic of interest. The questionnaire had four parts: first part consisted of general questions (age, gender, latest grade); the second part examined some general questions about their gaming habits (if they play games, how often, what games, what kind of games); the third part had to with more specific questions (specific areas of language, skills they improved by gaming); and the fourth part was more about the influence and benefits of gaming outside the classroom. The link to the questionnaire was given to students during the classes to fill in, the researcher being present all the time in order to help if necessary. The questionnaire consisted of 28 questions, a series of descriptive statistical analyses (e.g. mean, percentage and range) were performed on the quantitative data. Some of the questions included answers: multiple choice, open answers, strongly agree, agree, disagree, and strongly disagree, not at all, very little, somewhat, a lot, substantially. Some questions were repetitive in a way that students could answer them like multiple choice or open answers depending on the students' ability and willingness to write or just circle. Either way an answer would be provided.

At the beginning, the participants were asked to read each question carefully, to be honest, and to provide a response for all the questions. They were informed about the research and reason for doing the research; they were more than willing to participate since most of them play online games, so the topic of the research was something they were really interested in. The participants needed approximately 15 minutes to fill out the questionnaire.

\section{Results}

Part 1.

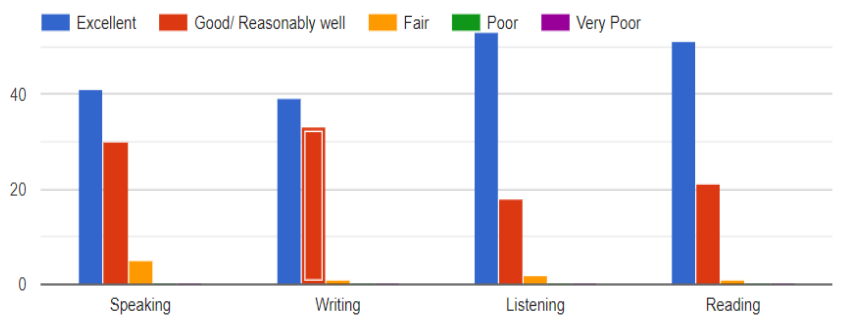

Q1. Please rate your English proficiency by choosing the appropriate answer for each of the four skills.

The most proficient areas of English language are listening and reading, followed by speaking, and the least proficient skill being writing (Figure 1).

\section{Q2. How old are you?}

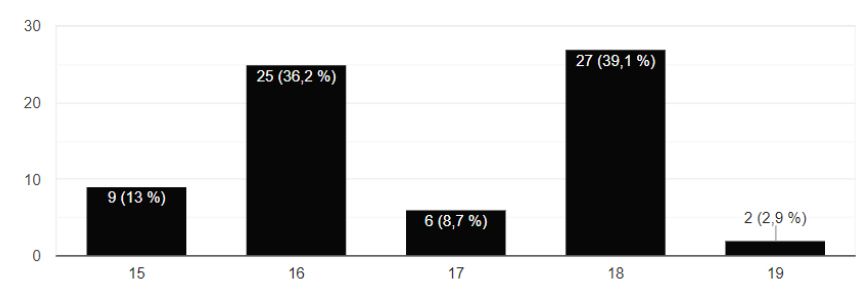

The graph shows that most of the students are 18 years old, followed by 16 years old, but as presented all grades are included, from the $1^{\text {st }}$ to the $4^{\text {th }}$ grade (Figure 2).

Q3. Gender of the participants: both of the genders were included in the research as presented (Figure 3).

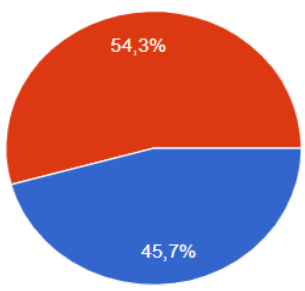




\section{Eucation and \&umanities \\ by MAP - Multidisciplinary Academic Publishing}

THE INFLUENCE OF ONLINE GAMES ON LEARNING ENGLISH VOCABULARY IN HIGH SCHOOLS IN BOSNIA AND HERZEGOVINA

Adela Mašić and Aida Tarabar

Q4. What is your latest grade from the English language course?

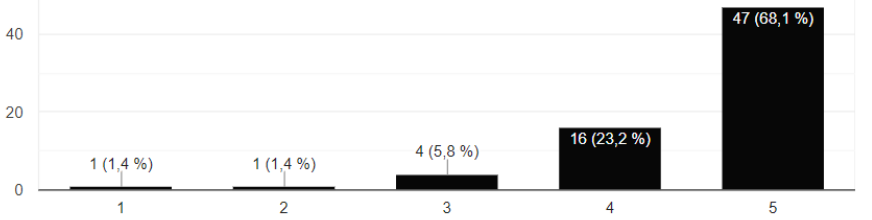

Majority of participants answered that their latest grade in English was 5 (68,1\%), followed by 4 $(23,2 \%)$, which implies that they are more than capable to understand and answer the questions well (Figure 4).

As presented in the first part of the questionnaire, most of the participants are 18-year-olds, with the latest grade in English language 5 (excellent), most proficient in listening and reading, and almost the same number of both girls and boys play online video games.

\section{Part 2.}

Q5. Do you play or have you ever played English video games on computer, console, web browser or mobile device?

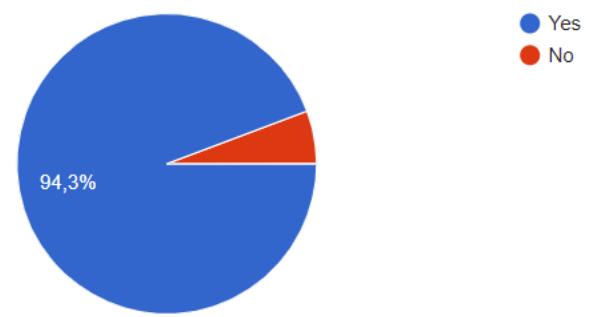

As the graph shows a huge percentage of the participants $(94,3 \%)$ said that they have played video games (Figure 5).

Q6. If you responded positively to the fifth questions, please state how often you play computer games:

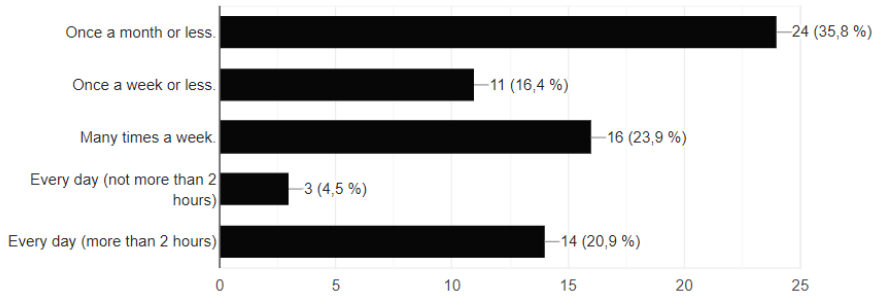

Students who gave a positive answer to Q5. mainly play games once a month or less $(35,8 \%)$, followed by many times a week $(23,9 \%)$, and there are those who play the games every day more than 2 hours $(20,9 \%)$ which is also a high percentage (Figure 6).

Q7. How old were you when you first started playing computer games?

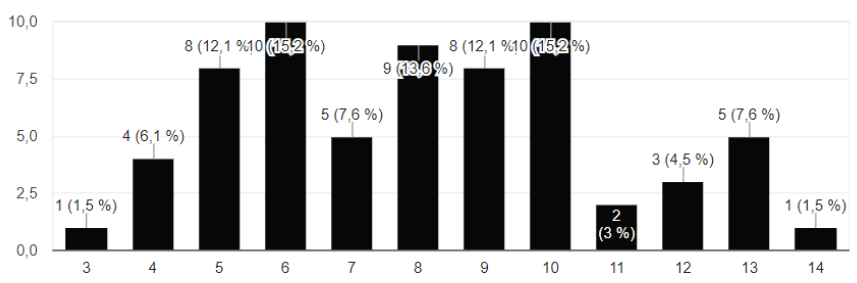

Very interesting answers were given to this question; ages ranging from 3-14 years old, though most of them started playing computer games at age 6 and age 10, respectively (Figure 7).

Q8. When you play computer games, for how long do you usually play during the day?

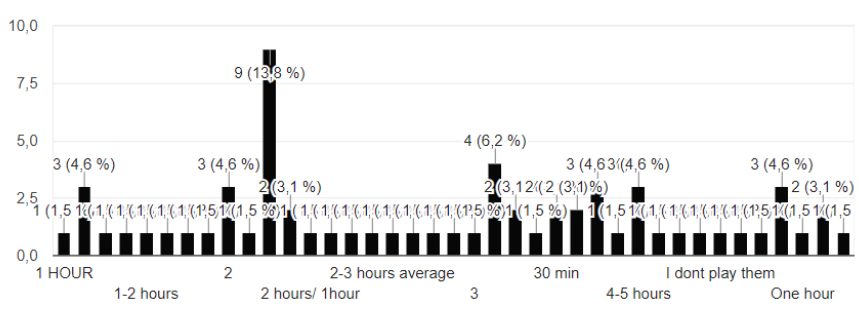

When asked to specify how many hours a day they usually play, participants gave different answers from: I do not play them, to 4-5 hours a day, the most of them playing approximately 2 hours a day $(13,8 \%)$ (Figure 8 ).

Q9. When asked what was the first game that they played students named many different games from the most played to the least played as following: Super Mario, GTA, Fifa 10, Sims, Minecraft, Counter Strike, Kingdom Hearts, Battlefield, My Little pets, League of Legends, Call of Duty, Winx, Hugo, Snake, Tetris, Candy Crush, etc. as we can see games depend of the age and interests, thus so many different genres.

Q10. Participants were asked to say which games they prefer; single player or multiplayer games, and as we can students prefer Multiplayer games (53,7\%) (Figure 9). 


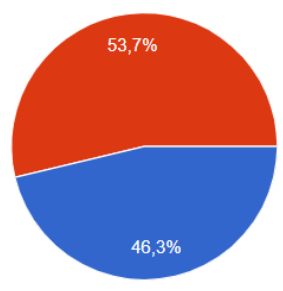

Single player games Multiplayer games

Q11. Do you play computer games with?

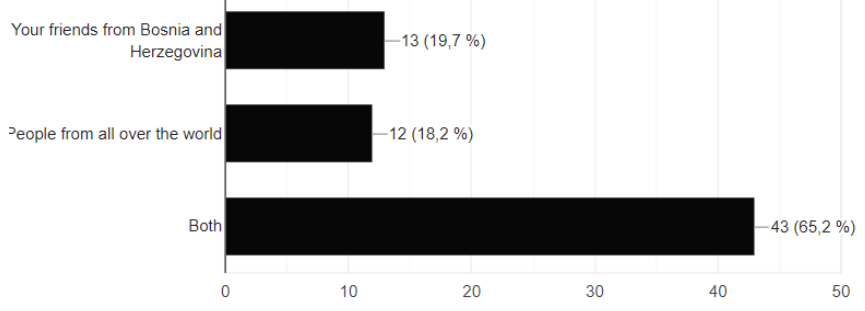

When asked with whom they play more friends from Bosnia and Herzegovina or people all over the world, 65,2\% answered both (Figure 10).

The second part of the questionnaire was related to their gaming habits. A very high percentage of the participants (94,3\%), play online games; most of them once a month or less $(35,8 \%)$, but there is also a high percentage who play every day more than 2 hours $(20,9 \%)$. They started playing online games at a very young age some of them were just 3 or 4 years old, but mostly at the age of 6 and 10 respectively. 53,7\% play multiplayer online games with both their friends from Bosnia and Herzegovina and all over the world; the list of the games they provided as the games they play was rather long.

\section{Part 3.}

Q12. /13. When asked to specify the game/ games they learnt most English from answers were very different varying from: every game I played I have learnt something new, every game new word, way too many to count all of them, but some of them are Call of duty bo 3, cs:go, League of legends, Fortnite, mostly games on random websites, all of them; one of them said that he/she did not learn English via games.
Q. 14.1/14.2 Do you find gaming vocabulary useful outside the classroom? If yes, how?

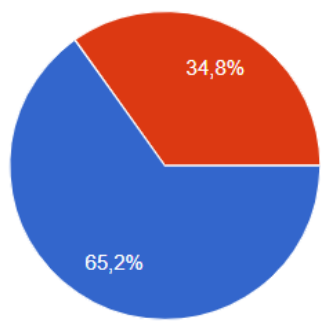

Yes

No

$65,2 \%$ answered yes, and the examples they gave were very interesting: speaking and understanding slang words, being able to understand native speakers, gaming vocabulary is actually the real vocabulary, useful phrases, well it helps me to learn new words and it's more interesting than someone just telling you, it develops our language skill in day to day communication, I have learnt certain words, that otherwise I wouldn't have known, to communicate with people from different countries, to understand articles on the internet, to learn new things, I've learnt a lot of terminology for easier communication in gaming, there isn't a thing such as "gamer vocabulary", because they use normal English words and phrases, talking with friends, you learn to adapt to different situations with a diverse vocabulary (GG (good game), noob (newbie), pickaxe, axe, birch, oak, spruce, planks, armor stand, leggings, chess plate, chest, dragon), in that way, words stay in our heads much longer (Figure 11).

Q15. What skills of English language have you found most useful in games, and they were given a choice.

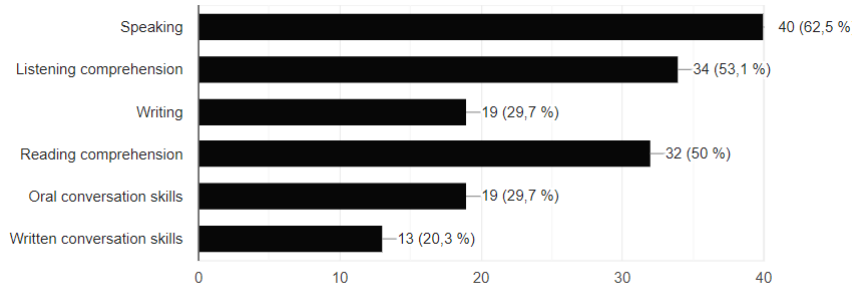

As presented in the chart the most useful skill used in games is speaking (62,5\%) (Figure 12).

Q16. I believe that playing computer games has improved/has contributed to the improvement of my English: 


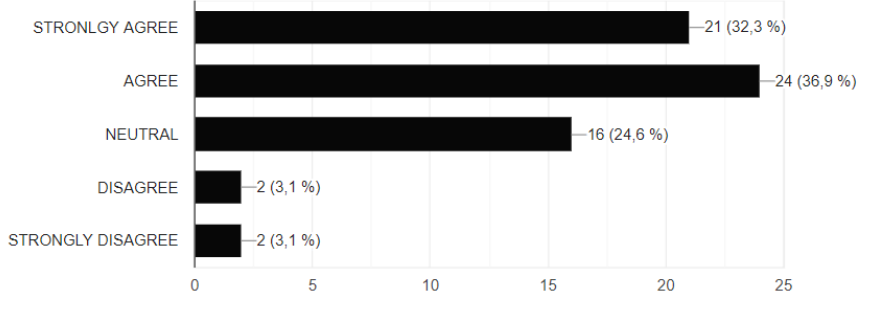

Most of the participants either agree (36,9\%) or strongly agree (32,3\%) (Figure 13 ).

Q17. What kind of areas of language have you learnt or what have you improved in when gaming in English?

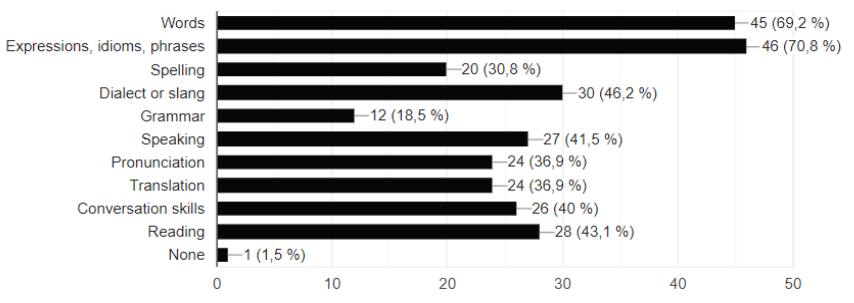

The areas of English that they mostly improved due to the games are expressions, idioms, phrases (70,8\%) and words (69,2\%) (Figure 14).

Q18. When asked to specify what skills in particular they learnt or improved most of them answered reading, but mention equally other skills such as: speaking, listening, and writing.

Q19. They had to specify which has gaming more improve spoken or written language skills:

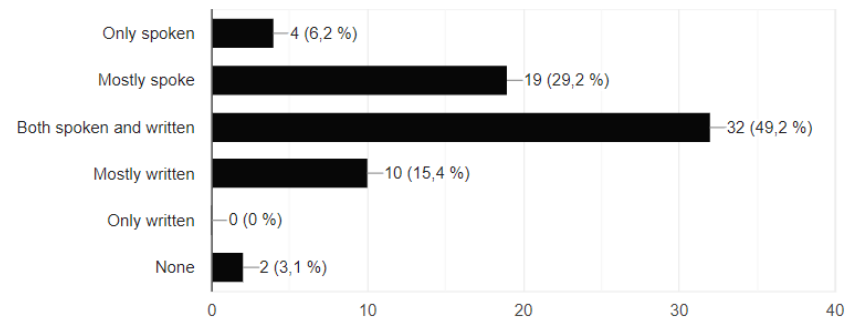

Most of them said both $(49,2 \%)$ (Figure 15$)$.

In the $3^{\text {rd }}$ part they were asked to specify how they benefited from playing online games in terms of English language. In the answers given they mostly said that they benefited from every game they play in terms of vocabulary; the skill mostly used is speaking; and the language used is both spoken and written. Majority agrees or strong- ly agrees that online games contributed to the improvement of their English language.

\section{Part 4.}

Q20. Have the skills you have acquired through video games benefited you at school?

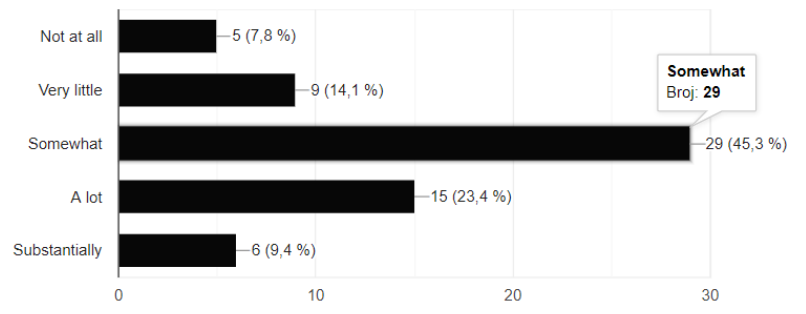

As presented, 45,3\% answered somewhat, following with a lot $(23,4 \%)$ (Figure 16$)$.

Q21. Do you feel that gaming ENHANCES your English studying, in other words, it helps you study English more effectively at school as well? If yes, how?

What is interesting to notice is that the participants gave various answers and explanations, but the answers are mostly tied, meaning Yes (7,1\%)- No (7,1\%).

Q22. Have the skills you have acquired through video games benefited you elsewhere outside games and studies?

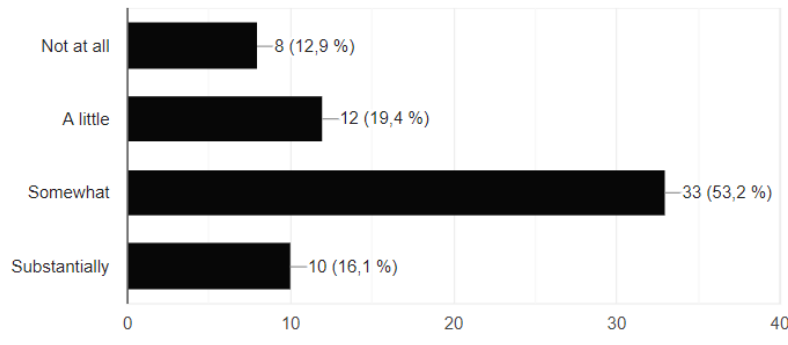

More than a half of them answered Somewhat $(53,2 \%)$ (Figure 17$)$, which is very interesting since in the next question:

Q23. If you feel that the skills you have acquired through video games benefited you outside the games, please tell how you have used these skills, they gave so many different examples:

Well, with my communication skills that were improved by video games, I am able to easily talk to anyone anywhere in English, while speaking to tourists, reading English texts etc., it has improved 


\section{Esucation and doumanities \\ by MAP - Multidisciplinary Academic Publishing}

THE INFLUENCE OF ONLINE GAMES ON LEARNING ENGLISH VOCABULARY IN HIGH SCHOOLS IN BOSNIA AND HERZEGOVINA

Adela Mašić and Aida Tarabar

my communication skills, to communicate with other people players, and to have more themes to talk about, mostly understanding slang, also it has helped a lot in communication learning new things, developing reflexes and many more, well, my English vocabulary was better by the years, because, in the same time, I was learning English at home and in school, I have been approached by tourists and I told them directions they needed.

Q24. To what extent do you believe English computer games benefit learning the language?

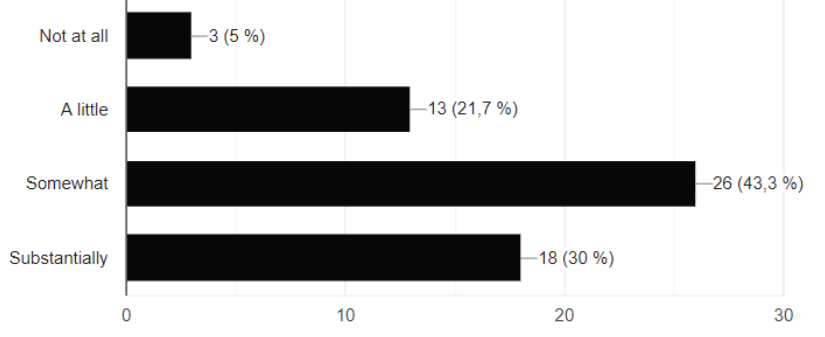

Most of them answered Somewhat (43,3\%), followed by the Substantially (30\%) (Figure 18).

Q25. If you believe that playing computer games facilitates learning English, please describe what kind of skills you believe the players learn or improve. Some of the answers given:

Writing, speaking, reading, listening, words, communication and listening, spoken English and new words, idioms and slang, idioms, phrases and communication skills mostly, pronunciation of lesser known words and phrases which benefits us in the terms of speaking and vocabulary lessons, communication, learning vocabulary and easier sentencing, depends on the game, some games encourage speaking while other encourage writing, they improve reading, vocabulary and in some cases listening and understanding, mostly writing, reading and English vocabulary.

Q26. Related to motivation:

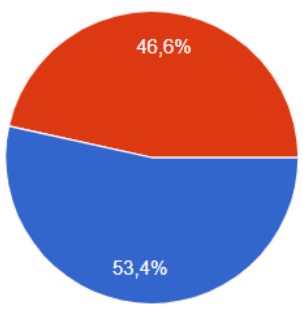

To play games in order to learn English language better

To learn English in order to play games better
Most of the students said that they learn English in order to play games better $(53,4 \%$ ) (Figure 19).

Q27. Do you think that online games would be a good tool to use in schools, especially English language classes? Why/Why not? Answers they gave were very interesting since most of them think that would be a good thing due to the fact that games are fun and motivating. :

Depending on the game, it could be used as a way to make students want to learn, or rather have fun while still learning; yes, it would help students to learn to communicate, I do think that online games would be a good tool to learn English, I think there are a lot of fun games that could help in learning English, Yesss because it's a WAYY better way to get the kids interested in what they are learning, people like new ways to learning and could benefit them in some way, Yes, because they can improve communication skills which are really important in learning a language, Yes because of the different phrases where we can learn how exactly and when we should use them, I think games would be a good tool to use in English class, because that is something innovative and different, that would keep the student entertained for a longer period of time resulting in increased interest in learning English and better results. It could also have drawbacks, but they can be avoided by limited usage of games in class, they could be useful in terms of having one class where we play games and then write and discuss phrases and words and grammar used in that game, well they would, as long as they where education based and had a use in education, Yes. The kids learn better when they have fun.

Q28. If possible give one example of how an online computer game can be used in a classroom, and describe its benefits in terms of vocabulary, grammar, communication, pronunciation, etc.

They really gave some interesting and good suggestions:

Some games improve knowledge on certain words, for example cooking games could be played in class and could also help in developing vocabulary connected to the topic. The same goes for variety of other topics, such as pets, health, music, geography, science and computers and many more. Also, many games require a lot of listening (to instructions for example) and reading, which improves those abilities and also keeps students 


\section{Eoveation and \&umanities \\ by MAP - Multidisciplinary Academic Publishing}

entertained for much longer. Whilst listening to the way the words are pronounced in a game, students would improve pronunciation, because otherwise they don't have many ways of listening to English speaking. Example: A character in a game said a random sentence and now the students have to translate it and analyze it (which tense it is). There are games for everything. So, for example kids could learn food words if they played cooking games. Myb some multiplayer games like csl.6 where kids from class will talk with each other on speakers specifically in English.

In the $4^{\text {th }}$ part they were asked to decide whether or not online games benefited them at school and outside school, and if they though online games should be used at school to help them learn the language. Interesting to notice that $45,3 \%$ said somewhat, followed by a lot $(23,4 \%)$ regarding school; and $53,2 \%$ also said somewhat outside school. Then in Q.23 they provided a long list of examples where and how they benefited by playing online games in the real life situations. Regarding motivation $53,4 \%$ said that they learn English in order to be able to play games better; and they agreed that using online games in the classroom would be useful and motivating; and gave some very interesting examples how to use online games in class.

\section{Discussion}

The main aim of this research paper was to try to determine whether or not playing online games helps students improve their vocabulary.

From the answers given by the participants, it is obvious that online games have a considerable influence on language learning due to the fact that most of them are highly motivated to learn new words in order to improve their performance in the game. What is clear from this research is that online games present a great resource for learning and expanding vocabulary, not just words, but expressions, phrases, slang; because majority of participants said that every game they play provide a huge amount of new words. The other very important finding of the questionnaire was the effect online games have on communication skills; they help people with speaking skills, since most of them play multiplayer games with both non-native and native speakers of English language. Also, most of them said that the vocabulary they learnt in the game helped them a lot outside it as well, in the real life situations. All of the above findings were in ac- cordance with the findings of González-González and Blanco-Izquierdo (2012), Thorne et al., (2009), Reinders and Wattana (2011), Chen and Johnson (2004, as cited in Rudis \& Poštić, 2018; Yip and Kwan (2006), da Silva (2014), Rankin et al. (2006), Theodorsen (2015), Uuskoski (2011).

When asked whether or not online games should be included in the teaching process, as a tool for learning new vocabulary and practicing speaking skills students mainly answered that they would love that because games are fun, interesting, motivating, and that would be something new and innovative and as such they would create a positive atmosphere and increase interest in learning a language. All of the findings were consistent with the findings of Rankin et al. (2006), Suh et al. (2010), Kim et al. (2013), Warschauer and Healey (1998, as cited in Sørensen \& Meyer, 2007), Connolly et al. (2012), Nagle et al. (2014).

One thing that was very interesting, and which was contrary to expectations is that when asked about their proficiency in English language and were given the options of the skills (Ql.), according to results the most proficient skill was listening then reading, speaking was on the third place. Yet, later in the results we can see that games mostly have effect on vocabulary and speaking.

\section{Limitations}

There are some limitations regarding this study. The first limitation is that this study should be done with more participants from different schools both primary and secondary, so the sample might be too small to generalize.

The second limitation is that the study was done only with the students as participants, from their point of view. In some further studies teachers' perspective might as well be included, which would give a better insight, and some pretest and posttest of specific vocabulary should be given.

\section{Conclusion}

To conclude, it is obvious that there is a connection between playing online games and acquiring new vocabulary. Proper understanding of the words is very important for the game and the players in order to achieve the objectives and win. The better understanding the better result, so players are highly motivated to start learning new words and phrases in order to make progress, and pass a level. It also proves that playing online games can 


\section{esoucation and doumantities \\ by MAP - Multidisciplinary Academic Publishing}

THE INFLUENCE OF ONLINE GAMES ON LEARNING ENGLISH VOCABULARY IN HIGH SCHOOLS IN BOSNIA AND HERZEGOVINA

Adela Mašić and Aida Tarabar

contribute to improvement of language acquisition in the classroom and teachers might consider using them as a special aid. By using online games in classrooms both teachers and students would benefit.

\section{References}

Connolly, T. M., Boyle, E. A., MacArthur, E., Hainey, T., \& Boyle, J. M. (2012). A systematic literature review of empirical evidence on computer games and serious games. Computers \& Education, 59(2), 661686. https://doi.org/10.1016/j.compedu.2012.03.004.

Da Silva, R. L., 2014. Video Games as Opportunity for Informal English Language Learning: Theoretical Considerations. The ESPecialist, 35(2), 155-169, 1-15. Retrieved from: http://revistas. pucsp.br/index.php/esp/article/viewFile/21465/15692 on 16 July 2021.

González-González, C., \& Blanco-Izquierdo, F. (2012). Designing social videogames for educational uses. Computers \& Education, 58(1), 250262. https://doi.org/10.1016/j.compedu.2011.08.014

Hubbard, P. and Bradin Siskin, C. (2004) Another look at tutorial CALL. ReCALL, 16(2): 448-461.

Kim, P.W., Kim, S.Y., Shim, M., Im, C.H., and Shon, Y. M. (2013). The influence of an educational course on language expression and treatment of gaming addiction for massive multiplayer online role-play game (MMORPG) players. Computers \& Education, 63, 208-217. doi: 10.1016/j.compedu.2012.12.008

Nagle, A., Wolf, P., Riener, R., \& Novak, D. (2014). The Use of Player-centered Positive Reinforcement to Schedule In-game Rewards Increases Enjoyment and Performance in a Serious Game. International Journal of Serious Games, 1(4). https:// doi.org/10.17083/ijsg.vli4.47

Petry, N.M., and O'Brien, C.P. (2013). Internet gaming disorder and the DSM-5. Addiction 108, 1186-1187. doi:101111/add.12162

Rama, Black, R., Es, V., \& Warschauer, M. (2012). Affordances for second language learning in World of Warcraft. ReCALL, 24(3), 322-338.

Rankin, Y., Gold, R., \& Gooch, B. (2006). 3D role-playing games as language learning tools. Eurographics, 25(3).
Reinders, H. and Wattana, S., 2011. Learn English or die: The effects of digital games on interaction and willingness to communicate in a foreign language. Retrieved from: http://www.digitalcultureandeducation.com/cms/wpcontent/ uploads/2011/04/dce1049_reinders_2011.pdf (accessed on November 17, 2016).

Rudis, D. \& Poštić, S. (2018). Influence of video games on the acquisition of the English language. Verbum. 8. 112. 10.15388/Verb.2017.8.11354

Sørensen, B.H., \& Meyer, B. (2007). Serious Games in language learning and teaching - $a$ theoretical perspective. Retrieved from:www.digra.org/ $\mathrm{dl} / \mathrm{db} / 07312.23426$

Sublette, V.A., and Mullan, B. (2012). Consequences of play: a systematic review of the effects of online gaming. Int. J. Ment. Health Addict. 10,0323. doi: $10.1007 / \mathrm{sl} 1469-010-9304-3$

Suh, S., S.W., and Kim, N. J. (2010). Effectiveness of MMORPG-based instruction in elementary English education in Korea. J. Comput. Assist. Learn. 26, 370-378.doi: 10.1177/1059840512449653

Theodorsen, J. H., 2015. L2 acquisition from video games with minimal exposure. Available from: https://www.ntnu. edu/documents/1535402/35615794/ $\mathrm{Master}$ a J H

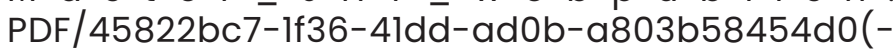
accessed on November 17, 2016).

Uuskoski, O., 2011. Playing video games: A waste of time... or not? Exploring the connection between playing video games and English grades. Available from: https:helda.helsinki.fi/bitstream/ handle/10138/35037/playingv.pdf (accessed on November 17, 2016).

Florence W. M. Yip \& Alvin C. M. Kwan (2006) Online vocabulary games as a tool for teaching and learning English vocabulary, Educational Media International, 43:3, 233249, DOI: $10.1080 / 09523980600641445$ 